\title{
Creeping from the Grave - The Return of Dracula
}

\section{Crișan, Marius-Mircea, ed. Dracula: An International Perspective. Palgrave Macmillan, 2018. pp. 280.}

In Our Vampires, Ourselves (1995), Nina Auerbach argues that "[t]here is no such creature as 'The Vampire,' there are only vampires" (5). The newest addition to vampire studies, Dracula: An International Perspective (2018), aims at emphasizing the transformative nature of the allpervading symbol by tracing its evolution from Stoker's 19th century novel to its present-day (re)presentations. Having, once again, crept from its grave, the vampire reveals itself as the most enduring of all monsters, mutating with each generation of writers. The vampires that populate the papers of the volume illustrate the different ways in which historical and cultural contexts have reimagined Stoker's archetype. Due to their protean nature, they have managed to escape the confines of literature and infiltrate all media.

The volume comprises fifteen papers written by international scholars, along with a framing introduction by Marius-Mircea Cri $\square$ an.The volume begins with William Hughes's discussion on the ongoing controversy concerning the definition of "Irish Gothic." By emphasizing the mutual exclusivity of the two concepts that constitute the definition, Hughes argues that the triadic canon of the 19th century Irish Gothic (Charles Maturin, Bram Stoker, and Joseph Sheridan Le Fanu) can only be unified by its consistency of professional sophistication. Accordingly, the stylized employment of rhetoric which characterizes the triad points towards the presence of an exceptionally educated and professional authorship (34), which Hughes illustrates by comparing the medical investigation in Le Fanu's A Glass Darkly (1872) and Stoker's Dracula (1897). In the following paper, Donatella Abbate Badin analyzes Romances set in Italy (a subgenre of the Irish 
Gothic) by focusing on Charles Maturin's novel The Fatal Revenge; or, The Family of Montorio (1807), anonymous novelette The Castle of Savina, or the Irishman in Italy. A Tale (1807), and two short stories written by Joseph Sheridan Le Fanu. Badin argues that the demonization of Italy in Irish Gothic mirrors the demonization of the Anglo-Irish by the English. Much like the description of Ireland by English writers and of Transylvania by Bram Stoker, the imaginatively constructed spaces of Italy reveal, in Badin's words, "the inner conflicts of a troubled collective psyche" (48) of the Anglo-Irish. Through focusing on the imagological construction of East-Central Europe in Edgar Allan Poe's short stories, the next paper continues the discussion of imaginary spaces. LucianVasile Szabo and Marius-Mircea Cri $\square$ anargue that both Le Fanu and Poe constructed EastCentral Europe as haunted, anticipating Stoker's Dracula. The authors conclude that the two most important aspects of Dracula - a mysterious land which still haunts the collective memory of its readers and the attention to technological innovations - epitomize Poe's representation of EastCentral Europe in his short story "Metzengerstein" (1832). Sam George's paper, on the other hand, draws a parallel between the two most powerful archetypes of the 19th century - Bram Stoker's Count Dracula and the Pied Piper, originally published as Die Kinder zu Hameln (1816-1818) by the Brothers Grimm. What ultimately connects the two archetypes is their association with Transylvania and, therefore, their identification as the Other, which is best visible in Robert Browning's relocation of the Grimms' myth. Comparing Stoker's Dracula with F.M. Murnau's movie Nosferatu (1922), the paper examines the ways in which the Dracula myth has traveled to Germany by revealing the figure of the colonizing Other, present in all of the aforementioned narratives. Through the analysis of Stoker's notes and sources, Hans Corneel de Roos' paper aims at dispersing some of the "certitudes" regarding Count Dracula - his identification with the historical leader of Wallachia, Vlad III Dracula, and the assumption that Bram Stoker did not determine the precise location of the Count's castle. Roos' hypothesis is that Stoker was aware of several voivodes from the historical regions belonging to contemporary Romania (i.e. Mihai Viteazul), but that he decided to deliberately muddle up his references in order to prevent the possibility of authentication. As for the Count's castle, Roos argues that Stoker wanted to provide a convincing location for his narrative, but, paradoxically, that too convincing a location would have revealed the fictitiousness of his construct. Roos' meticulous research offers a fresh perspective on the location of Dracula's castle by positioning it at Mount Izvorul. Drawing inspiration from Vladimar 
Asmundsson's Icelandic version of Dracula, Powers of Darkness: The Lost Version of Dracula (1900), Clive Bloom's paper traces the similarities between the imagological constructs of Transylvania and between Dracula and Jack the Ripper. Much like Stoker's Transylvania, Asmundsson's East End is a disorienting space of otherness, and Bloom argues that the two constructs are displaced from reality, both simulacra without origin. They embody places of psychological dislocation, eventually leading to ontological alienation, which, in turn, has the potential for unleashing violence (132). They are fictitious constructs that, somehow, managed to overpower reality itself.

The next three papers discuss some of the aspects related to the development of Dracula tourism. Duncan Light suggests giving greater attention to the touristic dimension of Stoker's novel, often dismissed as irrelevant. He positions Dracula as a novel of "restless mobility" (139) by identifying five types of tourism - business, health, occidental, political, and dark tourism. Marius-Mircea Cri $\square$ an'spaper discusses the connection between Castle Hunedoara, built by the Voivode of Transylvania John Huniady, and the Dracula myth as represented in movies such as Vlad (2003), Transylvania (2009), and in documentaries such as A Night in Dracula's Castle (2001), an episode of The Scariest Places on Earth (2000-). Cri $\square$ an'shistorical/literary approach leads to the conclusion that Stoker was aware of the significance of Castle Hunedoara in Transylvania's history, but that the connection is often exaggerated. Kristin L. Bone's paper explores the impact Anne Rice's Interview with the Vampire (1976), Stephanie Meyer's Twilight novels, and Bram Stoker's Dracula (1897) have had upon associated locations: New Orleans, home to events such as the Annual Vampire Lestat Anne Rice Ball; Forks, visited by numerous Twilight fans; and Whitby in the United Kingdom and Bran Castle in Romania, unified through their identification with the Dracula myth. Throughout the paper, Bone stresses both the advantages and disadvantages of these associations.

The following papers address the vampire's evolution from literature to contemporary media. By focusing on movies such as Drakula's Death (1921), Nosferatu (1922), Dracula (1931), Horror of Dracula (1931), Dracula (1979), Nosferatu: Phantom der Nacht (1979), and Bram Stoker's Dracula (1992), John Edgar Browning traces the rebirth of Dracula's narrative voice in relation to contemporary moral, cultural, and technological stimuli. Browning concludes that the myth is 
culturally (re)produced. In Jeffrey Jerome Cohen's words, the "myth" returns in different clothing to be read within the matrix of social, cultural, literary, and historical relations that generate it (6). Drawing inspiration from Dracula (1897), Anne Rice's Interview with the Vampire (1976) and The Vampire Lestat (1985), Nancy Schumann analyzes the vampire's emotion and identity as reflected in its gender. Focusing on the journey from Dracula's unemotionality to Lestat's and Louise's emotionality, Schumann argues that vampires have underwent a process of humanization as a result of acquiring the role of the unmediated narrator. Schumann also traces the similarities between Stoker's and Rice's portrayal of women who, eventually, become a threat to the status quo. In the following paper, Magdalena Grabias discusses Bram Stoker's legacy in relation to contemporary productions such as Underworld (2003), The Twilight Saga (2008-12), Hemlock Grove (2013-15), and Victor Frankenstein (2015). Grabias argues that these productions differ from their 20th century predecessors, primarily in their portrayal of the "monster" - the modern-day vampire has metamorphosed, no longer making our skin crawl with its hideous otherness. Dorota Babilas's paper discusses the portrayal of familial structures in Son of Dracula (1974), Fearless Vampire Killers (1967), and Dracula and Son (1976), comparing them to contemporary productions. Babilas argues that the turning point in the presentation of families came with Interview with the Vampire (1994), which portrays a homosexual or, at least, a homosocial structure (248). Furthermore, she argues that movies such as Vamps (2012), Hotel Transylvania (2012), and Dracula Untold (2014) (re)introduced the concept of new motherhood/fatherhood, suppressing one's individualism in favor of one's family. Although she discusses the cultural shift to "Vlad the Dad" (253), Babilas concludes by saying that some stories are better left untold. The final paper, written by Carol Senf, traces the evolution of Gothic spaces from Horace Walpole's The Castle of Otranto (1764) to the narratives written by H.P. Lovecraft and Stephen King, and the television series The Walking Dead (2010-), developed by Frank Darabont. Senf argues that the transition from ruined castles and abbeys in remote locations, such as envisioned in Anne Radcliffe's A Sicilian Romance (1790), to urban landscapes, such as those in King's Salem's Lot (1975), was facilitated by the publication of Bram Stoker's Dracula (1897).

Dracula: An International Perspective offers a multifaceted perspective on the subject of the vampire, drawing inspiration from literature, movies, and television series. Even though it 
approaches the vampire mythos chronologically, the volume can, at times, seem discontinued because of the application of both synchronic and diachronic perspectives. The fifteen chapters included in the volume function as separate papers that can be read without having extensive knowledge of the mythos, which makes it legible for scholars and general readers alike. It is an invaluable reading for those who have just embarked upon their vampiric journey. However, for scholars already immersed in the discussion, certain arguments could seem commonsensical, especially those pertaining to tourism. Furthermore, with regard to academic studies, the theoretical background is somewhat lacking in the sense of references and discussions of existing theorists in the context of the arguments some of these papers postulate. Nevertheless, the volume is a valuable addition to Dracula studies because it traces the ebb and flow, the concentration, integration, dissolution, concealment, and appropriation of the mythos. It succeeds in encapsulating the vampire's elusiveness, moving across periods, genres, and disciplines.

\section{Works Cited}

Auerbach, Nina. Our Vampires, Ourselves. University of Chicago Press, 1997.

Cohen, Jeffrey Jerome, ed. Monster Theory: Reading Culture. University of Minnesota Press, 1996.

Cri $\square$ an,Marius-Mircea, ed. Dracula: An International Perspective. Palgrave Macmillan, 2018.

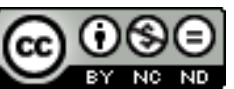

Creative Commons Attribution-NonCommercial-NoDerivatives 4.0 International License 